\title{
Predicting Cereal Root Disease in Western Australia Using Soil DNA and Environmental Parameters
}

\author{
Grant J. Poole, Martin Harries, D. Hüberli, S. Miyan, W. J. MacLeod, Roger Lawes, and A. McKay
}

First and seventh authors: South Australian Research and Development Institute, Gate 2b Hartley Grove, Urrbrae, SA 5064 Australia; second author: Department of Agriculture and Food, Western Australia, PO Box 110, Geraldton, WA 6530 Australia; third and fifth authors: Department of Agriculture and Food, Western Australia, 3 Baron-Hay Court, South Perth, WA 6151 Australia; fourth author: Department of Agriculture and Food, Western Australia, Lot 12 York Rd., Northam, WA 6401 Australia; and sixth author: CSIRO Ecosystem Sciences and Sustainable Agriculture Flagship, Wembley, WA 6913 Australia.

Current address of G. J. Poole: Syngenta Seeds Inc., 29128 Wells Rd, PO Box B, Cheney, WA 99004.

Accepted for publication 23 March 2015.

\begin{abstract}
Poole, G. J., Harries, M., Hüberli, D., Miyan, S., MacLeod, W. J., Lawes, R., and McKay, A. 2015. Predicting cereal root disease in Western Australia using soil DNA and environmental parameters. Phytopathology 105:1069-1079.

Root diseases have long been prevalent in Australian grain-growing regions, and most management decisions to reduce the risk of yield loss need to be implemented before the crop is sown. The levels of pathogens that cause the major root diseases can be measured using DNA-based services such as PreDicta B. Although these pathogens are often studied individually, in the field they often occur as mixed populations and their combined effect on crop production is likely to vary across diverse cropping environments. A 3-year survey was conducted covering most cropping regions in Western Australia, utilizing PreDicta B to determine soilborne

Rhizoctonia solani (anastomosis group [AG]-8), Gaeumannomyces graminis var. tritici (take-all), Fusarium pseudograminearum, and Pratylenchus spp. (root-lesion nematodes) on wheat roots for 115, 50, and 94 fields during 2010, 2011, and 2012, respectively. A predictive model was developed for root health utilizing autumn and summer rainfall and soil temperature parameters. The model showed that pathogen DNA explained 16 , 5 , and $2 \%$ of the variation in root health whereas environmental parameters explained 22,11, and $1 \%$ of the variation in 2010, 2011, and 2012, respectively. Results showed that $R$. solani AG-8 soil pathogen DNA, environmental soil temperature, and rainfall parameters explained most of the variation in the root health. This research shows that interactions between environment and pathogen levels before seeding can be utilized in predictive models to improve assessment of risk from root diseases to assist growers to plan more profitable cropping programs.
\end{abstract} pathogen levels and visual assessments to score root health and incidence of individual crop root diseases caused by the major root pathogens, including

Root diseases that limit small grain cereal yields (Triticum aestivum L., Hordeum vulgare L., and Avena sativa L.) are prevalent across Western Australia and have varying impact dependent upon agroecological zones, management practices, and seasonal environmental conditions (2). The advent of minimum-tillage practices increased the occurrence of root diseases and pathogens in Western Australia (2,25). The main root disease pathogens are Rhizoctonia solani J. G. Kühn anastomosis group (AG) 8 (common name Rhizoctonia root rot); Gaeumannomyces graminis var. tritici J. Walker (common name take-all); Pratylenchus neglectus (Rensch) Filipjev \& Schuurmans Stekhoven, P. teres, and P. thornei Sher \& Allen (root-lesion nematodes); Fusarium pseudograminearum O’Donnell \& T. Aoki (teleomorph Gibberella coronicola T. Aoki \& O'Donnell) and F. culmorum (Wm. G. Sm.) Sacc. (teleomorph unknown) (causal agents of crown rot); Heterodera avenae Wollenweber (cereal cyst nematodes); and Bipolaris sorokiniana (Sacc.) Shoemaker (syns. Helpminthosporium sativum Pammel, C. M. King \& Bakke and $H$. sorokinianum Sacc.) (causal agent of common root rot) $(2,10)$. These species occur across Australia and other parts of the world, including the Pacific Northwest (PNW) of the United States and Turkey, and historically have been studied individually $(2,15,17,31,33,35,43,51)$. However, in reality, these species occur as mixed populations in cereal cropping systems $(15,26,36,37,55)$. In Western Australia, root diseases cause

Corresponding author: G. J. Poole; E-mail: grant.poole@syngenta.com

http://dx.doi.org/10.1094/PHYTO-07-14-0203-R

(C) 2015 The American Phytopathological Society
Additional keywords: Bipolaris sorokiniana, common root rot, crown rot.

substantial root damage and subsequent yield loss in cereals, with annual losses estimated by Brennan and Murray (30,31) for $R$. solani, F. pseudograminearum, and Gaeumannomyces graminis var. tritici to be $\$ 27,7$, and 4 million per annum, respectively. Others have suggested substantial yield losses to wheat due to root-lesion nematodes $P$. neglectus and $P$. thornei in Australia and throughout the world $(33,37,53,58-60)$.

The focus of surveys and ecological studies have been on these various individual root diseases in replicated plot trials conducted throughout the United States, Australia, Europe, and New Zealand $(3,4,6-9,11,12,14,20,22,23,32,34,39,41,43,52,62)$. Plant pathologists generally accept the concept that disease is a result of the interactions between the pathogen, host, and environment (1). In the case of take-all, environmental conditions can play a significant role in disease expression regardless of the inoculum levels $(8,20,35)$. Others have shown that crop rotation and tillage management practices have had significant effects on expression of Rhizoctonia bare patch $(16,18,19,22,41)$. Okubara et al. (34) reported significant interactions between environmental climatic factors of temperature and rainfall with $R$. solani AG-8 and $R$. oryzae pathogen DNA. $R$. solani AG-8 pathogen DNA concentration was negatively correlated with precipitation; that is, higher concentrations under lower rainfall conditions. Okubara also found lower concentrations of $R$. solani AG-8 pathogen DNA following a broadleaf crop. Several have reported the significant effect of no-tillage and crop rotation practices on the prevalence of these root diseases $(13,15,18,23,34,38,40,41,45,50)$.

The Western Australia cropping region is characterized by a Mediterranean environment, with strong winter dominant rainfall 
and hot dry summers. Stephens and Lyons (57) regressed the rainfall from various weather stations throughout Western Australia with wheat yields to develop 16 agrometeorological zones. They reported that autumn rainfall and finishing rains after July were the most critical for wheat yield (57). DNA-based methods were developed in 1995 to estimate pathogen levels for G. graminis var. tritici and Rhizoctonia spp. (27,35). Soil-based DNA-based methods have been developed to detect the major root pathogens to aid in surveys and ecological studies $(18,34,35,49)$. There have been several attempts to model the relationships between environment and disease to predict severity of take-all, eyespot, and crown rot $(4,13,21,39)$. Lawes and Renton (24) used root diseases in a predictive model known as Land Use Sequence Optimizer (LUSO) that estimates the break crop effect based on variables including price, crop yield, nitrogen fertilizer cost, and weed load thresholds.

DNA-based technology has allowed for potentially more accurate assessment of soilborne pathogen levels that can be utilized in modeling cereal root disease development. Herdina and Roget (21) developed a DNA-based soil assay to predict take-all disease risk. Schoeny et al. (46) modeled take-all risk based on relating disease incidence and severity to winter wheat yield. Bithell et al. (8) showed that the relationship between presown G. graminis var. tritici soil DNA concentration and take-all disease development in crop was a logarithmic function dependent upon the environmental conditions during the growing season, and used this information to develop four disease risk categories.

Through the development of high-throughput DNA-based assays to estimate pathogen levels of a broad range of soilborne pathogens by the South Australian Research and Development Institute (SARDI) root disease testing service (RDTS), large-scale surveys can be conducted to investigate possible interactions between pathogen levels, environment and disease. SARDI's RDTS offers a range of soil-based DNA available commercially for growers and researchers for the estimation of cereal root disease risk assessment. Root disease incidence and severity is usually assessed between seedling stage and anthesis $(20,33,39,41,43,44,46,51,53,56)$. In the survey described here, root health was assessed at approximately anthesis to more closely reflect the final state of the health of the root system and the cumulative effect of root disease at the end of the season during grain fill. Research focused on this time frame because it was postulated that this would show the greatest effects of all the root diseases cumulatively. The objectives of this research were to model the relationship between soilborne pathogens levels assessed presowing using DNA-based assays, environment, and root health at anthesis utilizing data collected over 3 years from cropping fields in Western Australia.

\section{MATERIALS AND METHODS}

Sampling of field sites and root health disease assessments. The intention of this study was to focus on cereal root diseases for continuous wheat rotations; therefore, fields in wheat production for each year were selected. History of the previous crop was recorded to assess disease occurrence under different crop rotation conditions. Survey sites included 184 fields located across the major wheat-producing regions of Western Australia, from Albany in the south to Geraldton in the north. Of these locations, some fields that lacked viable data were eliminated and only 115,50 , and 94 were included in the analysis for the years 2010, 2011, and 2012, respectively. There were 21 fields that were consistently sampled across the 3 years covered in the study. Samples were taken at the seedling (June to July) and anthesis (September to October) phases of development (approximately 6 weeks after emergence for the seedling phase). Preliminary data analysis showed that plant-based disease assessments taken at anthesis were more accurate and descriptive of the wide range of cereal root diseases being assessed in this study. Although root diseases such as Rhizoctonia root rot and take-all are often assessed during the seedling stage, those of common root rot and Fusarium crown rot express themselves later in the season during the anthesis phase of development. For this reason, the authors felt that the anthesis timing would reveal a greater expression and damage assessment for the diverse biology involved with these cereal root diseases.

Forty plants were systematically sampled from a 1-ha area in each field. Each 1-ha area was divided into four replication areas with an area of 25 by $100 \mathrm{~m}$ for sampling with an Accucore probe (Adelaide, SA, Australia), with samples approximately $10 \mathrm{~m}$ apart. GPS coordinates were recorded for each field site using a Garmin Etrex 12 (Olathe, KS) channel device on World Geodetic System 1984 datum (WGS84). Roots and soil surrounding samples were sealed in a labeled plastic bag, foliage extending out of the bag. The entire sample, root, soil and foliage was placed in a paper bag and sent to Department of Agriculture and Food of Western Australia (DAFWA) in Perth, WA for visual assessment of disease. The number of plants (incidence) with symptoms of the major root diseases, including Rhizoctonia root rot, take-all, Fusarium crown rot, common root rot, and root-lesion nematode, were recorded. Rhizoctonia root rot symptoms were scored according to the degree of spear tipping on the roots; take-all symptoms were recorded according to blackened lesions on roots; Fusarium crown rot symptoms were scored according to the degree of browning on the first stem internode; root-lesion nematode symptoms were scored according to the lack of lateral branching and degree of browning on roots; and common root rot symptoms were scored according to the degree of blackening on the subcrown internode. In total, 40 samples (including stem and root mass) per field sample were scored, representing a combined and cumulative "disease severity" or "root health" score for each of the aforementioned root diseases on a 0 -to-5 disease severity scale that will be referred to as root health, where $0=$ no disease, $1=1$ to $5 \%$ disease, $2=6$ to $25 \%$ disease, $3=26$ to $50 \%$ disease, $4=51$ to $75 \%$ disease, and $5=76$ to $100 \%$ disease.

DNA pathogen level estimations (PreDicta-B). Soil sampling was conducted with an AccuCore soil probe (Spur soil probes, Adelaide, SA, Australia) coring device with a 10-mm width to a depth of $10 \mathrm{~cm}$, as suggested by the manufacturer for sampling and according to previous research conducted by SARDI (36). In total, 40 cores were taken from the 1-ha area per field surveyed to make a total sample that weighed approximately 500 g. Presow samples were taken in March to April and postharvest samples were taken in approximately November to December to estimate DNA levels both prior to and at the end of the season. DNA extraction was conducted and analyzed in a TaqMan-based assay in 384-well plates according to Ophel Keller et al. (36). DNA-based primers are proprietary to SARDI RDTS. Results from the PreDicta-B DNA analysis were reported for the major aforementioned root disease pathogens, including $R$. solani AG-8, G. graminis var. tritici, F. pseudograminearum, F. culmorum, B. sorokiniana, P. neglectus, $P$. thornei, and $P$. teres, in picograms per gram of soil.

Climate and weather data. Weather data for each individual year of the study $(2010,2011$, and 2012) were retrieved from 15 weather stations (within $30 \mathrm{~km}$ of each sample location) from the DAFWA climate data website and assigned to survey fields based on the nearest proximity to a weather station and the relevant weather conditions, with some interpretation of local conditions (http://www.agric.wa.gov.au). Seasonal data for 2010, 2011, and 2012 was summarized according to weather data for mean soil temperature of monthly combinations of February-March and April-May, and a sum of rainfall for the months of January, February, and March and autumn to early winter months of April, May, and June rainfall for each of the 3 years was utilized as well as for 30-year averages from the aforementioned DAFWA climate website. These specific months were selected and combined in their respective groups according to data from a logistic regression 
testing the effect of each specific month of the year for soil temperature, ambient air temperature, and rainfall on disease incidence and severity or root health. In addition to logistic regression, a procedure known as Step-AIC was used in R, version 2.15.3, to select the greatest effects of most significant environmental and DNA parameters on each of the respective root disease incidence and the overall disease severity or root health. Step-AIC is a stepwise comparison of model quality with each data parameter by Akaike Information Criteria (AIC) (61).

Meteorological data collection and statistical analysis. Long-term averages were retrieved from the Australian Bureau of Meteorology website from 14 weather stations in close proximity (within $50 \mathrm{~km}$ ) to each sample location (http://www.bom.gov. $\mathrm{au} / \mathrm{wa} /$ ?ref $=$ hdr ) according to the data available from each location. For the long-term data, we used the climate parameters mean monthly ambient air temperature calculated for similar variables as those described above for February-March and April-May soil temperatures $\left({ }^{\circ} \mathrm{C}\right)$ as well as January-February-March and AprilMay-June rainfall $(\mathrm{mm})$ from the same monthly periods. Additional parameters included elevation and soil type. Soil type textures at each location were generically classified as sand $=1$, sandy loam $=$ 2 , loam $=3$, silty loam $=4$, and clay or clay loam $=5$, based on interpretations made by the lead author from summaries made by DAFWA soil scientists in Geraldton, Western Australia. Pearson's correlations were calculated between elevation and maximum, minimum, and mean annual soil temperature, as well as mean annual precipitation, disease incidence of the complex of root diseases, and disease severity; and PreDicta-B DNA of each specific root disease organism was calculated to determine initial relationships between parameters.

Means, coefficient of variation (CV) and standard deviations representing soil temperature, rainfall, overall frequency of disease incidence, disease severity or root health, as well as soil DNA levels of various fungi associated with the root disease complex were calculated using SAS (v9.3; SAS Institute Inc., Cary, NC.). Species incidence represented an annual mean occurrence across samples of Rhizoctonia root rot, take-all, Fusarium crown rot, common root rot, and root-lesion nematode symptoms from 40 randomly sampled stem, crown, and root sections from each surveyed field. The relative detection of DNA for $R$. solani AG-8, G. graminis var. tritici, $F$. pseudograminearum, F. culmorum, B. sorokiniana, and Pratylenchus spp. were converted to $\log +1$ values and analyzed accordingly in a logistic regression using SAS v9.3 for distribution.

Regional analysis according to cereal variety testing zones. Surveyed fields were placed within crop variety testing (CVT) zones published by the DAFWA to provide a basis for spatial analysis (57). Due to congruencies of weather data and geographical location, zones were statistically analyzed and combined for analysis of disease parameters on the basis of those analyses. Zone 1 represented a combination of high rainfall (450 to $750 \mathrm{~mm}$ ) and low rainfall ( 350 to $450 \mathrm{~mm}$ ). Zones 1 and 2 were combined on the basis of their geography to represent the northern region of Western Australia. Zone 2 comprised 53 fields within the mediumrainfall (325 to $450 \mathrm{~mm}$ ) southern region of Western Australia. Zone 3 comprised 26 fields within the medium-rainfall (325 to $450 \mathrm{~mm}$ ) north-central region of Western Australia. Zone 4 comprised 80 fields within the medium-rainfall (325 to $450 \mathrm{~mm}$ ) central region of Western Australia. Zone 5 comprised 33 fields within the mediumrainfall (325 to $450 \mathrm{~mm}$ ) zone of the south-central region of Western Australia. Zone 6 comprised agronomic zones of high (450 to $750 \mathrm{~mm}$ ) and medium ( 325 to $450 \mathrm{~mm}$ ) rainfall in the south-central and western regions of Western Australia. Due to an imbalance of field numbers in zones 1 through 4 and 9 through 12, as well as statistical similarities in preliminary regional analyses, the fields surveyed within these zones were grouped into their own zones to make six zones in total, to enhance the balance of sampled fields within agronomic zones. Long-term means of rainfall and temperature data from weather stations in close proximity to survey sites were obtained from the Australian Bureau of Meteorology website (Table 1). Disease incidence numbers (not proportions), DNA, and environmental (temperature and rainfall) parameters outlined previously were analyzed according to these CVT zones or regions in a general linear model procedure in SAS v9.3.

Logistic and tree regression analysis. In order to model the relationship between root disease, presow soil DNA levels, and environmental climate parameters, each disease incidence response was tested in a logistic and regression tree approach. The presence or absence of each respective root disease measured in the root disease complex, including Rhizoctonia root rot, take-all, crown rot, common root rot, and root-lesion nematodes for each of the total diseased plants out of the total 40 stem or root systems per field, were regressed against soil DNA (measured by PreDicta-B) and environmental April-May and February-March soil temperature as well as April-May-June and January-February-March precipitation parameters separately for each year (2010, 2011, and 2012) using logistic regression analysis with the logistic procedure in SAS v9.3. The terms for the Rhizoctonia root rot incidence logistic model were $R$. solani AG- 8 soil DNA per PreDicta B $\left(\beta_{\mathrm{i}} x_{\mathrm{i}}\right)$, correction factor $(C F)-R$. solani AG-8 soil DNA $(C F$ is the polynomial correction term calculated by squaring the DNA values used to fit them into the logistic model) $\left(\beta_{\mathrm{j}} x_{\mathrm{j}}\right)$, January-February-March rainfall $\left(\beta_{\mathrm{k}} x_{\mathrm{k}}\right)$, April-May-June rainfall $\left(\beta_{1} x_{1}\right)$, April-May soil temperature $\left(\beta_{\mathrm{m}} x_{\mathrm{m}}\right)$, February-March soil temperature $\left(\beta_{\mathrm{n}} x_{\mathrm{n}}\right)$, and the error term $\left(E_{\mathrm{ijklmn}}\right)$, where Rhizoctonia disease incidence $\left(Y_{\mathrm{ijklmn}}\right)=\beta_{\mathrm{i}} x_{\mathrm{i}}+\beta_{\mathrm{j}} x_{\mathrm{j}}+\beta_{\mathrm{k}} x_{\mathrm{k}}+\beta_{\mathrm{l}} x_{1}+\beta_{\mathrm{m}} x_{\mathrm{m}}+\beta_{\mathrm{n}} x_{\mathrm{n}}+E_{\mathrm{ijklmn}}$. Diagnostics on the logistic regression models did not indicate any extremely influential points.

In summarizing the root disease and soil DNA data, descriptive statistics did not explain the variation in the data, because there was a lack of relationship between the soil DNA and disease incidence data. Environment was postulated as having a potential effect due to disease-environment interactions described by the "disease triangle" postulated by plant pathologists, describing the relationship of disease as an interaction between the host plant, environment, and plant pathogen (inoculum) levels (1). Due to the large number of variables, their potential interactions with each other, and the nonlinearity of the disease data response, a regression decision tree approach that determined thresholds was used to model the disease response in addition to the logistic regression.

Regression tree analysis was conducted using the disease incidence, DNA, and environmental data in R version 2.15.3 (61). A disease severity or root health model was developed from the regression tree analysis utilizing survey data for the respective root disease pathogens (all pathogens involved in the root health disease severity rating) and environmental soil temperature and rainfall values. The terms for the regression tree analysis were $R$. solani AG-8

TABLE 1. Mean root health or disease severity and incidences (\%) of the major root diseases involved in the cereal root disease complex for the respective survey years

\begin{tabular}{|c|c|c|c|c|}
\hline \multirow[b]{2}{*}{ Ratings and disease incidence } & \multicolumn{4}{|c|}{ Incidence $(\%)$} \\
\hline & 2010 & 2011 & 2012 & Mean $^{x}$ \\
\hline Root health or disease severity ${ }^{y}$ & 0.5 & 1.0 & 1.3 & 0.9 \\
\hline Rhizoctonia root $\operatorname{rot}^{\mathrm{z}}$ & 15 & 27 & 43 & 28 \\
\hline Root-lesion nematode ${ }^{z}$ & 10 & 28 & 7 & 15 \\
\hline Take-allz & 6 & 7 & 5 & 6 \\
\hline Fusarium crown $\operatorname{rot}^{\mathrm{z}}$ & 0 & 3 & 24 & 9 \\
\hline Common root $\operatorname{rot}^{\mathrm{z}}$ & 3 & 3 & 2 & 2 \\
\hline
\end{tabular}

x Mean represents the average for each species isolated across the 2010, 2011, and 2012 survey years.

y Root health or disease severity was rated on a scale of 0 to 5 , where $0=$ no disease, $1=1$ to $6.25 \%$ disease, $2=6.25 \%$ to $25 \%$ disease, $3=26 \%$ to $50 \%$ disease, $4=51 \%$ to $75 \%$ disease, and $5=76 \%$ to $100 \%$ disease.

z Disease incidence proportions per field of Rhizoctonia root rot, root-lesion nematode, take-all, Fusarium crown rot, and common root rot are expressed as the proportion of plants out of 40 with disease per field. 
soil DNA per PreDicta B $\left(\beta_{\mathrm{i}} x_{\mathrm{i}}\right), C F-R$. solani $(\mathrm{AG}-8)$ soil DNA $\left(\beta_{\mathrm{j}} x_{\mathrm{j}}\right)$, G. graminis var. tritici soil DNA $\left(\beta_{\mathrm{k}} x_{\mathrm{k}}\right)$, P. neglectus soil DNA $\left(\beta_{1} x_{1}\right)$, $F$. pseudograminearum soil DNA $\left(\beta_{\mathrm{m}} x_{\mathrm{m}}\right)$, summer (JanuaryFebruary-March) rainfall $\left(\beta_{\mathrm{n}} x_{\mathrm{n}}\right)$, autumn (April-May-June) rainfall $\left(\beta_{\mathrm{o}} x_{\mathrm{o}}\right)$, autumn (April-May) soil temperature $\left(\beta_{\mathrm{p}} x_{\mathrm{p}}\right)$, summer (February-March) soil temperature $\left(\beta_{\mathrm{q}} x_{\mathrm{q}}\right)$ and the error term $\left(E_{i j k l m n}\right)$, where disease severity or root health $\left(Y_{i j k l m n}\right)=\beta_{\mathrm{i}} x_{\mathrm{i}}+$ $\beta_{\mathrm{j}} x_{\mathrm{j}}+\beta_{\mathrm{k}} x_{\mathrm{k}}+\beta_{1} x_{1}+\beta_{\mathrm{m}} x_{\mathrm{m}}+\beta_{\mathrm{n}} x_{\mathrm{n}}+\beta_{\mathrm{o}} x_{\mathrm{o}}+\beta_{\mathrm{p}} x_{\mathrm{p}}+\beta_{\mathrm{q}} x_{\mathrm{q}}+E_{\mathrm{ijklmn}}$. Environmental parameters of February-March and April-May soil temperature and rainfall were placed in the regression tree models along with the respective DNA and disease data obtained for each field. The models returned the predicted number of diseased plants with poor root health expected according to the model, given levels of pathogen DNA, root disease, and environmental parameters (autumn and summer soil temperature and rainfall) for each field.

\section{RESULTS}

The mean frequency of incidence from 40 randomly selected stem and root systems over the three survey years were the greatest for Rhizoctonia root rot $(28 \%)$ followed by root-lesion nematode (15\%), take-all (6\%), common root rot (3\%), and crown rot $(9 \%)$ (Table 1). Mean Rhizoctonia root rot incidence was the greatest for 2012 (42\%). Take-all and Rhizoctonia root rot incidence varied to the greatest degree across the 3 years. There were significant differences between years for Rhizoctonia root rot, Fusarium crown rot, and common root rot disease incidences (Table 1). Rhizoctonia root rot disease incidence had the greatest correlation to root health disease severity over the three survey years $(r=0.68, P<0.0001)$ (Table 2$)$.

The mean root health disease severity rating among fields was $0.5(10 \%)$ in $2010,1.0(20 \%)$ in 2011 , and $1.3(26 \%)$ in 2012 , with a percent CV of 144, 139, and $66 \%$ for each year, respectively (Table 1). The range for root health disease severity ratings (rated 0 to 5) was from 0 to 31 in 2010, 0 to 72 in 2011, and 0 to 43 in 2012. The $R^{2}$ values and standard errors from Step-AIC revealed that soil temperature and rainfall parameters for the respective months selected had the greatest impact on disease severity and root health.

Of the five root diseases reported in this article, Rhizoctonia root rot and root-lesion nematode symptoms were rated at the greatest frequency (Table 1). Rhizoctonia disease incidence was most strongly correlated with $R$. solani AG-8 soil DNA but was also correlated with April-May-June rainfall $(r=-0.31, P<0.0001)$, and April-May soil temperature $(r=-0.31, P<0.0001)$ (Table 2$)$. Root health disease severity was most strongly associated with $R$. solani AG-8 soil DNA, weakly related to January-February-March and April-May-June rainfall, and negatively correlated with FebruaryMarch soil temperature $(r=-0.30, P<0.0001)$ (Table 2). Rootlesion nematode incidence was not significantly correlated with any soil DNA pathogen tests but was most closely associated with take-all incidence $(r=0.26, P<0.0001)$ and root health disease severity $(r=0.27, P<0.0001)$.
Detection of B. sorokiniana (45\%) and P. neglectus (39\%) soil DNA according to PreDicta-B was the greatest in the study across the 3 years. The percentage of fields with detectable levels of $R$. solani AG-8 soil DNA (23\%) was ranked third of all the pathogens across the 3 years and was the greatest in 2012, with substantial variation across years (Table 3). Detection of G. graminis var. tritici soil DNA only occurred in an average of $3 \%$ of the fields. Detection of $P$. thornei and $P$. teres was also low (3 and 9\%, respectively). Detection of $F$. pseudograminearum, B. sorokiniana, and $P$. neglectus was the greatest in 2012 (Table 3). There were weak associations between $R$. solani AG-8 soil DNA and monthly rainfall parameters as well as between $P$. neglectus soil DNA and soil temperatures. Presow and postharvest soil DNA level associations were the strongest for $P$. neglectus, $P$. thornei, B. sorokiniana, and $R$. solani AG-8, showing stability in populations from presow to postharvest sampling (Table 4).

Regional analysis utilizing CVT zones. When climate, disease, and pathogen DNA levels were analyzed according to CVT zones, there were significant differences between zones for Rhizoctonia root rot incidence and root health disease severity (Fig. 1; Table 5). Due to an imbalance of paddocks per zone, CVT zones were pooled according to similarities in locale and weather parameters and analyzed for Rhizoctonia root rot incidence and root health disease severity. The February-March and April-May soil temperatures were significantly lower in the four southern zones-zone 9 (H4), zone 10 (H5W), zone 11 (M5C), and zone 12 (M5W) - and lower for the northern zones-zone 2 (H2), zone 3 (L1), zone 4 (L2), and zone 5 (M1) - therefore, these were grouped into two different regions (Table 5). Zones 5 and 6 were

TABLE 3. Mean proportions (percentage of fields in Western Australia) of detectable soil DNA before sowing for each pathogen involved in the cereal root disease complex

\begin{tabular}{lrrrr}
\hline & \multicolumn{5}{c}{ Fields with detectable soil } \\
\cline { 2 - 5 } & DNA $(\%)^{\mathrm{y}}$ \\
\cline { 2 - 5 } Disease (common name), pathogen DNA & 2010 & 2011 & 2012 & Mean $^{\mathrm{z}}$ \\
\hline Rhizoctonia root rot, Rhizoctonia solani & & & & \\
$\quad$ AG-8 & 17 & 16 & 37 & 23 \\
Take-all, Gaeumannomyces graminis & 2 & 4 & 2 & 3 \\
$\quad$ var. tritici & 12 & 12 & 22 & 16 \\
Crown rot, Fusarium pseudograminearum & 37 & 48 & 51 & 45 \\
Common root rot, Bipolaris sorokiniana & & & & \\
Root-lesion nematodes & 38 & 30 & 50 & 39 \\
$\quad$ Pratylenchus neglectus & 6 & 0 & 4 & 3 \\
$\quad$ P. thornei & 11 & 8 & 9 & 9 \\
$\quad$ P. teres &
\end{tabular}

${ }^{y}$ Numbers represent proportions of fields with detectable soil DNA levels according to PreDicta-B within each year.

${ }^{\mathrm{z}}$ Mean represents the average for each species isolated across the 2010, 2011, and 2012 survey years.

TABLE 2. Pearson's correlation coefficients for disease incidence and severity compared with soil DNA levels for the most important soilborne pathogens involved in the cereal root disease complex

\begin{tabular}{|c|c|c|c|c|c|}
\hline \multirow[b]{3}{*}{ Disease, pathogen soil DNA } & \multirow[b]{3}{*}{ Rhizoctonia root rot } & \multirow[b]{3}{*}{ Disease severity } & \multicolumn{3}{|c|}{ Soil DNA } \\
\hline & & & Presow & Presow & Postharvest \\
\hline & & & Rhizoctonia solani & Pratylenchus neglectus & P. neglectus \\
\hline Rhizoctonia root rot incidence & 1.00 & 0.68 & 0.22 & 0.08 & 0.04 \\
\hline$P$ value & $\ldots$ & $<0.0001$ & 0.0005 & 0.21 & 0.56 \\
\hline Disease severity & $\ldots$ & 1.00 & 0.22 & 0.04 & 0.04 \\
\hline$P$ value & $\ldots$ & $\ldots$ & 0.0004 & 0.50 & 0.56 \\
\hline Presow $R$. solani AG-8 soil DNA & $\ldots$ & $\ldots$ & 1.00 & 0.17 & 0.05 \\
\hline$P$ value & $\ldots$ & $\ldots$ & $\ldots$ & 0.005 & 0.43 \\
\hline Presow P. neglectus soil DNA & $\ldots$ & $\ldots$ & $\ldots$ & 1.00 & 0.52 \\
\hline$P$ value & $\ldots$ & $\ldots$ & $\ldots$ & $\ldots$ & $<0.0001$ \\
\hline Postharvest $P$. neglectus soil DNA & $\ldots$ & $\ldots$ & $\ldots$ & $\ldots$ & 1.00 \\
\hline
\end{tabular}


characterized by cooler February-March and April-May soil temperatures with higher April-May-June rainfall soil temperatures (Fig. 1; Table 5). The 2010, 2011, and 2012 growing seasons represented distinct diversity in weather patterns (Table 6). The first

TABLE 4. Pearson's correlation coefficients for presow versus postharvest soil DNA levels according to PreDicta-B for the important soilborne pathogens involved in the cereal root disease complex for the 259 fields analyzed over the 3 years of the study $(2010,2011$, and 2012)

\begin{tabular}{lcc} 
Disease (common name), pathogen DNA detection $^{\mathrm{x}}$ & $r$ Value $^{\mathrm{y}}$ & $P$ value $^{\mathrm{z}}$ \\
\hline Rhizoctonia root rot, Rhizoctonia solani AG-8 & 0.32 & 0.0001 \\
Take-all, Gaeumannomyces graminis var. tritici & 0.16 & 0.009 \\
Crown rot, Fusarium pseudograminearum & 0.26 & 0.0001 \\
Common root rot, Bipolaris sorokiniana & 0.55 & 0.0001 \\
Root-lesion nematodes & & \\
$\quad$ Pratylenchus neglectus & 0.52 & 0.0001 \\
$\quad$ P. thornei & 0.69 & 0.0001 \\
$\quad$ P. teres & 0.31 & 0.0001 \\
\hline
\end{tabular}

x Pathogen DNA test utilized PreDicta-B for each pathogen and root disease represented.

y The $r$ value was calculated according to Pearson's correlation coefficients in SAS v9.3.

z $P$ values from Pearson's correlation analysis are considered significant at $P=0.05$ and below.

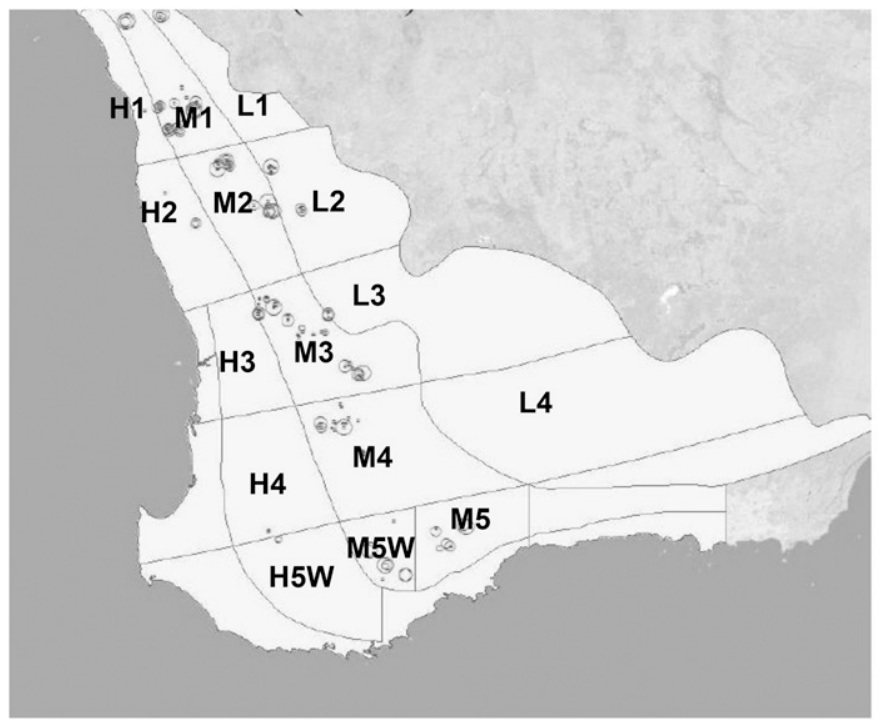

Fig. 1. Summary of survey locations, Rhizoctonia solani AG-8 soil DNA, and the cereal variety testing zones outlined by Stephens and Lyons (57) according to Western Australia rainfall and yield for broad-acre cereal grain crops. year of the survey, 2010, was characterized by the lowest JanuaryFebruary-March and April-May-June rainfall, which was lower than the other 2 years as well as the 30-year average. The 2011 growing season was characterized by a very wet summer (JanuaryFebruary) (in comparison with the other 2 years) and warmer autumn (April-May) temperatures. Significance and conclusions were interpreted with care from 2011 data, because the number of fields surveyed in that year was very low (50 fields). The 2012 growing season was characterized by a wet April-May (Table 6).

Rhizoctonia disease incidence and root health disease severity were significantly higher in zone 6 , characterized by high autumn rainfall and cooler autumn soil temperatures (Tables 5 and 7), compared with all other CVT zones in Western Australia. R. solani AG-8 pathogen DNA was numerically the greatest in zone 6 but not significantly different from zones 2 and 5 (Table 8). Root health disease severity was predicted to be $26 \%$ (Table 7). $R$. solani AG-8 pathogen soil DNA was significantly higher in zones 2,5 , and 6 (Table 8). Zone 6, representing 21 fields, also had the greatest levels of $G$. graminis var. tritici and $F$. pseudograminearum pathogen DNA. Zone 6, with the greatest levels of soilborne pathogen DNA for $R$. solani AG-8, G. graminis var. tritici, and F. pseudograminearum, also had the greatest level of disease severity (Tables 7 and 8).

$R$. solani AG-8 incidence logistic regression model. A logistic regression model used Rhizoctonia root rot incidence as the measured $y$ variable effect against parameters of $R$. solani AG-8 pathogen DNA, a polynomial $R$. solani AG-8 pathogen DNA correction factor (CF-R. solani [AG-8] pathogen DNA), and environmental factors (summer and autumn rainfall and soil temperature). When predicted levels of Rhizoctonia root rot incidence according to the logistic regression model were compared with actual levels measured for the 259 individual fields across the 3 years, the relationship was relatively strong $\left(R^{2}=0.29, r=0.54\right.$, $P<0.0001)$. When surveyed fields were placed into the respective

TABLE 6. Mean rainfall and soil temperature for the years included in the survey of Western Australia

\begin{tabular}{lccrr}
\hline Monthly weather parametery & 2010 & 2011 & 2012 & Mean $^{\mathrm{z}}$ \\
\hline January-February-March rainfall & 34 & 63 & 37 & 50 \\
February-March soil temperature & 33 & 31 & 28 & 24 \\
April-May-June rainfall & 61 & 99 & 103 & 142 \\
April-May soil temperature & 21 & 21 & 20 & 17 \\
\hline
\end{tabular}

y Rainfall represent a sum of the rainfall for the months outlined in centimeters and temperature represents the mean of the soil temperature for the months outlined in degrees Celsius.

z Mean represents the 30-year average for each weather parameter across the 2010, 2011, and 2012 survey years.

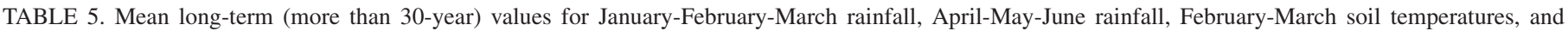
April-May soil temperatures for the modified cereal variety testing (CVT) zones ${ }^{\mathrm{w}}$

\begin{tabular}{|c|c|c|c|c|c|}
\hline \multirow[b]{2}{*}{ CVT zone ${ }^{\mathrm{x}}$} & \multirow[b]{2}{*}{$n^{\mathrm{y}}$} & January-February-March & \multirow{2}{*}{$\frac{\text { February-March }}{\text { Temp }\left({ }^{\circ} \mathrm{C}\right)}$} & \multirow{2}{*}{$\frac{\text { April-May-June }}{\text { Rainfall }(\mathrm{cm})}$} & \multirow{2}{*}{$\frac{\text { April-May }}{\text { Temp }\left({ }^{\circ} \mathrm{C}\right)}$} \\
\hline & & Rainfall (cm) & & & \\
\hline Zone 1 (H1, H2, L1, L2) & 45 & $38 \mathrm{~ns}$ & $33 \mathrm{a}$ & $113 \mathrm{a}$ & $23 \mathrm{a}$ \\
\hline Zone $2(\mathrm{M} 1)^{\mathrm{z}}$ & 53 & 40 & $31 \mathrm{~b}$ & $59 \mathrm{c}$ & $21 \mathrm{~b}$ \\
\hline Zone 3 (M2) & 26 & 39 & $31 \mathrm{~b}$ & $62 \mathrm{bc}$ & $21 \mathrm{~b}$ \\
\hline Zone 4 (M3) & 80 & 37 & $31 \mathrm{~b}$ & $73 \mathrm{~b}$ & $21 \mathrm{~b}$ \\
\hline Zone 5 (M4) & 33 & 55 & $28 \mathrm{c}$ & $74 \mathrm{~b}$ & $19 \mathrm{c}$ \\
\hline Zone $6(\mathrm{H} 4, \mathrm{H} 5 \mathrm{~W}, \mathrm{M} 5 \mathrm{C}, \mathrm{M} 5 \mathrm{~W})$ & 21 & 47 & $26 \mathrm{~d}$ & $105 \mathrm{a}$ & $18 \mathrm{~d}$ \\
\hline Mean & 43 & 43 & 30 & 81 & 21 \\
\hline
\end{tabular}

${ }^{w}$ Zones were pooled to improve balance of paddocks within zones. Rainfall amounts are expressed in centimeters per summation of January, February, and March based on long-term averages in centimeters. Soil temperature (Temp) is based on a mean of degrees Celsius per month delineated for months, including the months of February-March and April-May. Numbers followed by the same letter within a column were not significantly different across CVT zones at $P=0.05$ according to a least significant difference multiple range test; ns $=$ not significant at $P=0.05$.

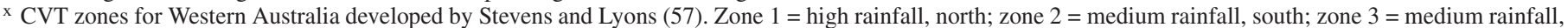
north-central; zone 4 = medium rainfall, central; zone 5 = medium rainfall, south-central; and zone $6=$ high and medium rainfall, south-central and west.

y Number of fields within each CVT zone.

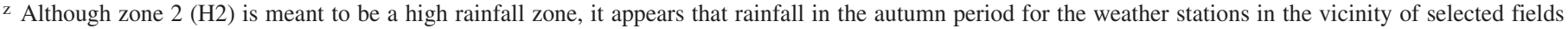
surveyed in this region reflected very low rainfall compared with the rest of the year. 
CVT zones and predicted and actual means of Rhizoctonia root rot incidence were calculated and compared according to the zones, the relationship was stronger $\left(R^{2}=0.69, P<0.0001\right)$, showing evidence of regional disease risk calculated by the model and levels actually measured. The highest predicted Rhizoctonia root rot incidence was in southern zones 9 (H4), 10 (H5W), 11 (M5C), and 12 (M5W) (Table 7).

Results showed that $R$. solani AG-8 pathogen DNA had a significant impact on disease severity in 2010 and 2012 but not 2011, which was characterized by higher January-February-March late-summer rainfall (Fig. 2; Table 9). $R$. solani AG-8 pathogen DNA explained the greatest amount of variation $(9 \pm 0.22 \%$ in 2010 and $2 \pm 0.15 \%$ in 2012) while environmental rainfall and soil temperature parameters explained approximately $4 \pm$ 0.005 to $5 \pm 0.13 \%$ cumulatively. January-February-March rainfall and February-March soil temperature had a significant impact on Rhizoctonia disease incidence, mainly in 2010 and 2012, and explained $4 \pm 0.05$ and $2 \pm 0.004 \%$, respectively, of the variation in Rhizoctonia root rot incidence. February-March and April-May soil temperatures were significant across all 3 years, with varying degrees of impact in each season. April-May soil temperatures had a positive effect on Rhizoctonia root rot incidence in 2010 and a negative effect in 2011 and 2012, while February-March soil temperatures had a negative impact on Rhizoctonia root rot incidence in 2010 and a positive effect in 2011 and 2012. All rainfall and soil temperature parameters explained $11 \pm 0.005 \%$ of the variation in 2010 and $4 \pm 0.13 \%$ of the variation in 2012 in the Rhizoctonia disease incidence model. $R$. solani AG- 8 pathogen
DNA seemed to have a more definitive impact on disease expression in 2010. The probability of Rhizoctonia root rot incidence was the greatest in 2010 under high April-May-June rainfall and in 2012 with higher February-March soil temperatures and lower JanuaryFebruary-March rainfall (Fig. 2).

The impact of $R$. solani AG-8 pathogen DNA was less in 2012 (explaining $2 \%$ of the variation), with greater effects of environment and greater probability of Rhizoctonia root rot incidence (ranging from approximately 60 to $90 \%$, with an exponential curve shape as AG-8 pathogen DNA increased from $\log \mathrm{DNA}=1$ to 3 ) under higher February-March soil temperatures and lower January-FebruaryMarch rainfall. There was less disease incidence under higher January-February-March rainfall and cooler February-March soil temperatures (ranging from approximately 25 to $75 \%$ as AG-8 pathogen DNA increased from log DNA $=1$ to 3) (Fig. 2C and D). There were not enough fields surveyed in 2011 to report results from that year in this part of the data analysis.

Root health disease severity regression tree model. When predicted values from the regression tree model for root health disease severity were compared with the actual measured values, there was a significant relationship $\left(R^{2}=0.38, r=0.71, P<0.0001\right)$ (Fig. 3). The regression tree analysis determined that environmental parameters of April-May-June rainfall, January-February-March rainfall, and February-March soil temperatures, as well as $R$. solani AG-8 pathogen DNA, were the most influential in estimating root health disease severity on a 0-to-5 scale. Root health disease severity predicted by the regression tree model was significantly correlated to actual disease severity (Fig. 3). When fields were

TABLE 7. Mean Rhizoctonia root rot incidence and disease severity estimates predicted by the regression tree model compared with actual measurements according to regions within cereal variety testing $(\mathrm{CVT}) \mathrm{zones}^{\mathrm{x}}$

\begin{tabular}{|c|c|c|c|c|c|}
\hline \multirow[b]{2}{*}{ CVT zoney } & \multirow[b]{2}{*}{$n$} & \multicolumn{2}{|c|}{ Rhizoctonia incidence } & \multicolumn{2}{|c|}{ Disease severity } \\
\hline & & Predicted $^{\mathrm{z}}$ & Actual & Predicted $^{\mathrm{z}}$ & Actual \\
\hline Zone $1(\mathrm{H} 1, \mathrm{H} 2, \mathrm{~L} 1, \mathrm{~L} 2)$ & 45 & $12 \mathrm{~b}$ & $9 \mathrm{c}$ & $0.90 \mathrm{~b}$ & $0.98 \mathrm{~b}$ \\
\hline Zone 2 (M1) & 53 & $9 \mathrm{~d}$ & $12 \mathrm{~b}$ & $0.80 \mathrm{bc}$ & $0.80 \mathrm{~b}$ \\
\hline Zone 3 (M2) & 26 & $8 \mathrm{~d}$ & $10 \mathrm{bc}$ & $0.75 \mathrm{c}$ & $0.80 \mathrm{~b}$ \\
\hline Zone 4 (M3) & 80 & $10 \mathrm{c}$ & $10 \mathrm{bc}$ & $0.80 \mathrm{bc}$ & $0.80 \mathrm{~b}$ \\
\hline Zone 5 (M4) & 33 & $11 \mathrm{c}$ & $8 \mathrm{c}$ & $0.80 \mathrm{bc}$ & $0.75 \mathrm{c}$ \\
\hline Zone $6(\mathrm{H} 4, \mathrm{H} 5 \mathrm{~W}, \mathrm{M} 5 \mathrm{C}, \mathrm{M} 5 \mathrm{~W})$ & 21 & $18 \mathrm{a}$ & $19 \mathrm{a}$ & $1.30 \mathrm{a}$ & $1.30 \mathrm{a}$ \\
\hline Mean & 43 & 16 & 13 & 0.89 & 0.90 \\
\hline
\end{tabular}

${ }^{x}$ CVT zones published by Department of Food and Agriculture of Western Australia (2006). Numbers followed by the same letter within a column are not significantly different at $P=0.05$ according to Duncan's least significant difference multiple range tests that were performed only on actual measurements.

y CVT zones were combined due to similarities in climate. Zone 1 = high rainfall, north; zone $2=$ medium rainfall, south; zone $3=$ medium rainfall, north-central; zone 4 = medium rainfall, central; zone $5=$ medium rainfall, south-central; and zone $6=$ high and medium rainfall, south-central and west.

z Predicted values for Rhizoctonia root rot incidence and disease severity are based on outputs of the logistic regression model developed to predict these parameters on the basis of pathogen DNA and seasonal soil temperature or rainfall parameters. Numbers represent the number of plants out of 40 per field with the potential to be diseased by Rhizoctonia root rot. Values were standardized according to the number out of 40 plants.

TABLE 8. Mean soil DNA levels measured by PreDicta-B for four of the most prevalent and wide-spread soilborne pathogens involved in the root disease complex according to regions within cereal variety testing $(\mathrm{CVT})^{\mathrm{u}}$

\begin{tabular}{|c|c|c|c|c|c|}
\hline \multirow[b]{2}{*}{ CVT zone ${ }^{\mathrm{v}}$} & \multirow[b]{2}{*}{$n$} & \multicolumn{3}{|c|}{ DNA levels (pg/g of soil) } & \multirow[b]{2}{*}{ Pratylenchus $^{\mathrm{Z}}$} \\
\hline & & Rhizoctonia $^{\mathrm{w}}$ & Gaeumannomyces ${ }^{\mathrm{x}}$ & Fusarium ${ }^{\mathrm{y}}$ & \\
\hline Zone 1 (H1, H2, L1, L2) & 45 & $9 \mathrm{~b}$ & $1 \mathrm{~b}$ & $29 \mathrm{~b}$ & $0.3 \mathrm{c}$ \\
\hline Zone 2 (M1) & 53 & $18 \mathrm{ab}$ & $0.8 \mathrm{~b}$ & $26 \mathrm{~b}$ & $10 \mathrm{a}$ \\
\hline Zone 3 (M2) & 26 & $1 \mathrm{~b}$ & $0.5 \mathrm{~b}$ & $4 \mathrm{~b}$ & $4 \mathrm{~b}$ \\
\hline Zone 4 (M3) & 80 & $6 \mathrm{~b}$ & $2 \mathrm{~b}$ & $23 \mathrm{~b}$ & $1 \mathrm{c}$ \\
\hline Zone 5 (M4) & 33 & $12 \mathrm{ab}$ & $2 \mathrm{~b}$ & $15 \mathrm{~b}$ & $2 \mathrm{c}$ \\
\hline Zone 6 (H4, H5W, M5C, M5W) & 21 & $31 \mathrm{a}$ & $6 \mathrm{a}$ & 346 a & $5 \mathrm{~b}$ \\
\hline Mean & 43 & 15.0 & 2.0 & 81.7 & 2.8 \\
\hline
\end{tabular}

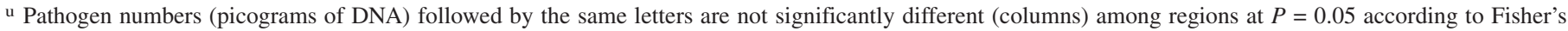
least significant difference multiple range test.

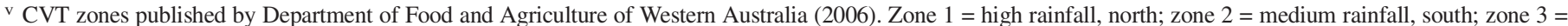
medium rainfall, north-central; zone $4=$ medium rainfall, central; zone $5=$ medium rainfall, south-central; and zone $6=$ high and medium rainfall, south-central and west.

${ }^{\mathrm{w}}$ Rhizoctonia solani (anastomosis group 8) is responsible for causing Rhizoctonia root rot.

x Gaeumannomyces graminis var. tritici is responsible for causing take-all.

y Fusarium pseudograminearum is responsible for causing crown rot.

z Pratylenchus neglectus is the main causal pathogen species of root-lesion nematode damage. Numbers represent the number of nematodes per gram of soil. 
placed into CVT zones, model results from the regression tree analysis showed stronger relationships between actual and predicted values $\left(R^{2}=0.94, P<0.0001\right)$ (Fig. 4). Results of the regression tree analysis showed disease levels of 6 to $54 \%$, with the most influential environmental and pathogen parameters being April-May-June rainfall, January-February-March rainfall, F. pseudograminearum pathogen DNA, $R$. solani AG-8 pathogen DNA, P. neglectus pathogen DNA, B. sorokiniana pathogen DNA, and G. graminis var. tritici pathogen DNA on root health and disease severity.

To interpret the regression tree, follow the tree to the left for results less than the critical values represented in the parentheses and to the right for those greater than the critical values in parentheses. Splits near the top of the tree were the most influential on root health, while those at the bottom were less. The regression tree model showed the greatest risk of decline in root health and increased disease severity (54\%) under conditions of April-MayJune rainfall greater than $66 \mathrm{~mm}$, low February-March soil temperatures (less than $34^{\circ} \mathrm{C}$ ), high $R$. solani AG-8 pathogen DNA (greater than $\log$ DNA $=0.5$ ), with lower levels of both $F$. pseudograminearum (less than log DNA $=1.1$ ) and B. sorokiniana pathogen DNA (less than log DNA $=1.7$ ) and low January-February-March rainfall (less than $22 \mathrm{~mm}$ ) (Fig. 5). It also showed that, under conditions of high April-May-June rainfall (greater than $66 \mathrm{~mm}$ ), January-February-March summer rainfall greater than $22 \mathrm{~mm}$ but less than $42 \mathrm{~mm}$ resulted in $26 \%$ disease severity (rating $=1.3$ on a 0 -to- 5 scale). These conditions and high F. pseudograminearum pathogen DNA levels (greater than $0.5 \mathrm{log}$ DNA) resulted in $21 \%$ disease severity.

P. neglectus pathogen DNA showed a significant effect on disease severity (32\%) under conditions of higher April-May-June rainfall
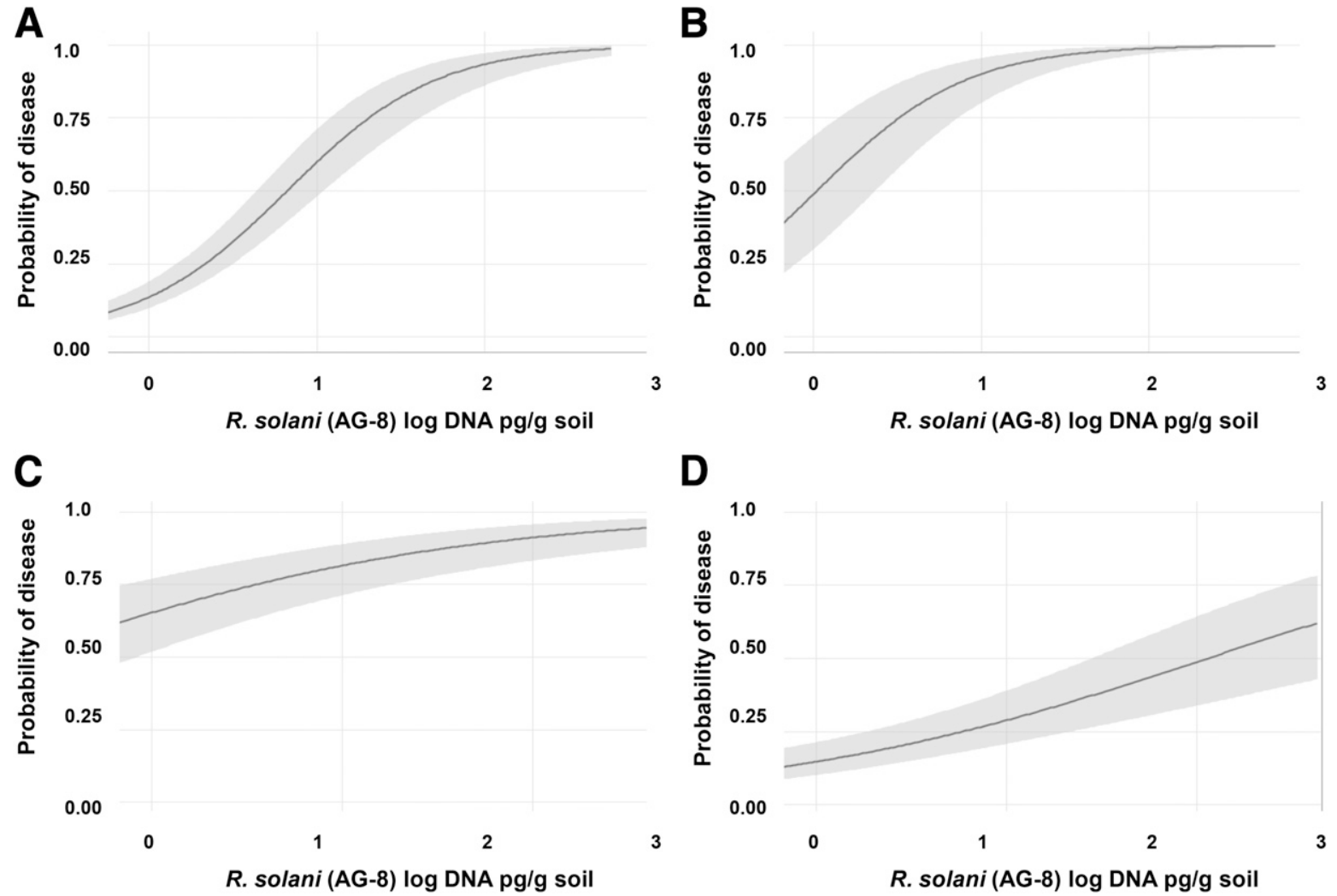

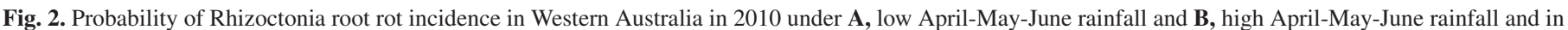

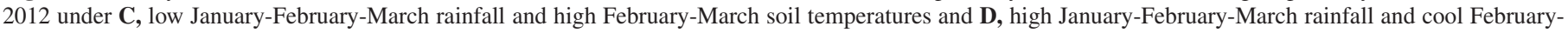
March soil temperatures as Rhizoctonia solani pathogen DNA increased from $\log =0$ to $\log =3$.

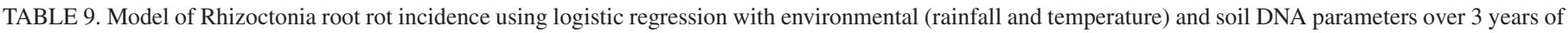
a survey study $(2010,2011$, and 2012)

\begin{tabular}{|c|c|c|c|c|c|c|}
\hline \multirow[b]{2}{*}{ Parameter } & \multicolumn{2}{|c|}{2010} & \multicolumn{2}{|c|}{2011} & \multicolumn{2}{|c|}{2012} \\
\hline & Estimate & $P$ value & Estimate & $P$ value & Estimate & $P$ value \\
\hline Intercept & 0.44 & 0.71 & 2.25 & 0.02 & 1.16 & 0.09 \\
\hline R. solani AG-8 DNA & 2.26 & $<0.0001$ & 0.37 & 0.22 & 0.85 & $<0.0001$ \\
\hline$C F-R$. solani $\mathrm{DNA}^{\mathrm{z}}$ & -1.04 & $<0.0001$ & 0.008 & 0.96 & -0.37 & $<0.0001$ \\
\hline \multicolumn{7}{|l|}{ Rainfall } \\
\hline January-February-March & -0.002 & 0.46 & 0.002 & 0.38 & -0.02 & $<0.0001$ \\
\hline April-May-June & 0.02 & $<0.0001$ & 0.005 & 0.005 & -0.0004 & 0.71 \\
\hline \multicolumn{7}{|l|}{ Soil temperature } \\
\hline April-May & 0.23 & 0.02 & -0.53 & 0.0002 & -0.21 & $<0.0001$ \\
\hline February-March & -0.25 & $<0.0001$ & 0.24 & 0.003 & 0.12 & 0.002 \\
\hline
\end{tabular}

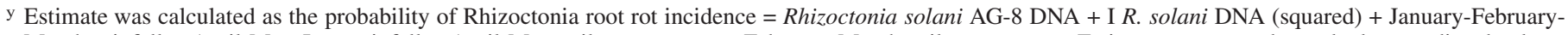
March rainfall + April-May-June rainfall + April-May soil temperature + February-March soil temperature. Estimates were used to calculate predicted values. $P$ value less than $P=0.05$ was considered a significant effect.

${ }^{\mathrm{z}}$ CF-Rhizoctonia solani soil DNA was squared and as a correction factor for soil DNA in the model to enable it to fit a polynomial curve. 


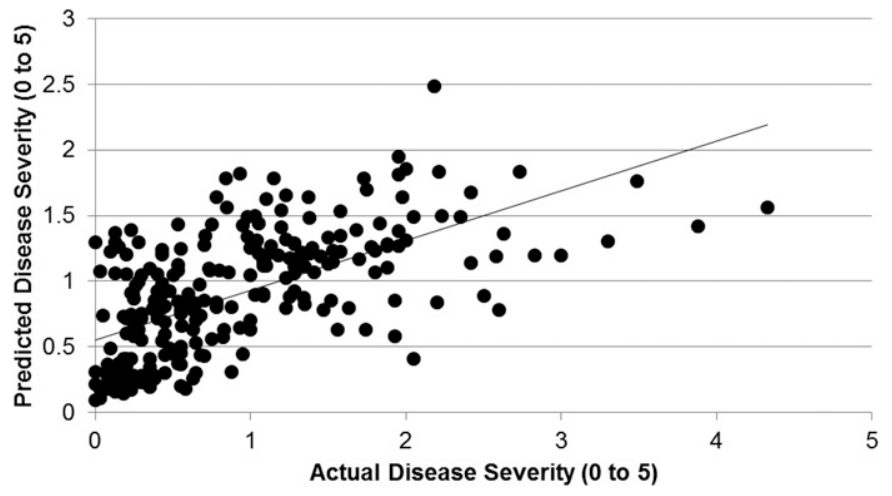

Fig. 3. Regression $\left(R^{2}=0.38, P<0.0001\right)$ of predicted values of disease severity (rated 0 to 5 ) according to the logistic regression model plotted against actual measured disease severity values across the 3 years of the Western Australia focus field survey.

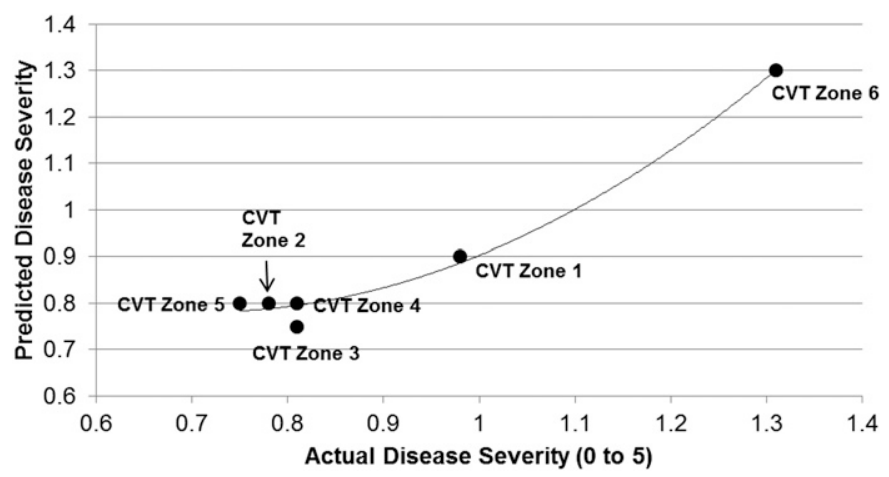

Fig. 4. Regression analysis $\left(R^{2}=0.94, P<0.0001\right)$ plot of predicted values of disease severity (rated 0 to 5 ) according to the logistic regression model plotted against actual measured disease severity values for cereal variety testing (CVT) zone means across the 3 years of the Western Australia focus field survey. (greater than $66 \mathrm{~mm}$ ), cooler February-march soil temperatures (less than $34^{\circ} \mathrm{C}$ ), lower $R$. solani AG- 8 pathogen DNA levels (less than $\log 0.5 \mathrm{DNA})$, and $P$. neglectus DNA levels greater than $\log$ $\mathrm{DNA}=0.28$ but less than log DNA $=3.5$. G. graminis var. tritici pathogen DNA significantly affected disease severity (26\%) under the aforementioned conditions, with April-May-June rainfall between 102 and $119 \mathrm{~mm}$ and G. graminis var. tritici pathogen DNA greater than log DNA $=0.52$ (Fig. 5). All of these pathogens seemed to interact together under conditions of high $F$. pseudograminearum (greater than $\log \mathrm{DNA}=1.1$ ) and $G$. graminis var. tritici pathogen DNA (greater than $\log$ DNA $=0.52$ ) and higher $R$. solani AG-8 pathogen DNA levels (greater than log DNA $=0.5$ ) all interacting with the aforementioned environmental conditions of cool February-March soil temperatures and higher April-May-June rainfall to result in $30 \%$ disease severity and decline in root health (Fig. 5).

\section{DISCUSSION}

This study documents the interactions between environmental conditions, pathogen DNA concentration in soil preseeding, and root disease expression in the crop at anthesis. Our research agrees with that of others and has shown that root health in cereals can be predicted with a certain level of confidence using both a logistic regression and regression tree approach, with significant $R^{2}$ values of 0.94 similar to that of Okubara et al. (34), Poole et al. (39), and Lawes et al. (24). The regression tree analysis showed that root health disease severity was greatest under higher April-May-June rainfall, cooler February-March soil temperatures, higher $R$. solani AG-8 soil DNA concentrations (DNA at greater than $0.5 \mathrm{log} \mathrm{pg} / \mathrm{g}$ of soil), lower levels of other soilborne pathogens (namely $F$. pseudograminearum, $P$. neglectus, and B. sorokiniana), and lower January-February-March summer rainfall. These results really showed that all of the pathogens interacted together in a competitive relationship, where $R$. solani AG- 8 seemed to dominate under lower summer rainfall and disease levels were

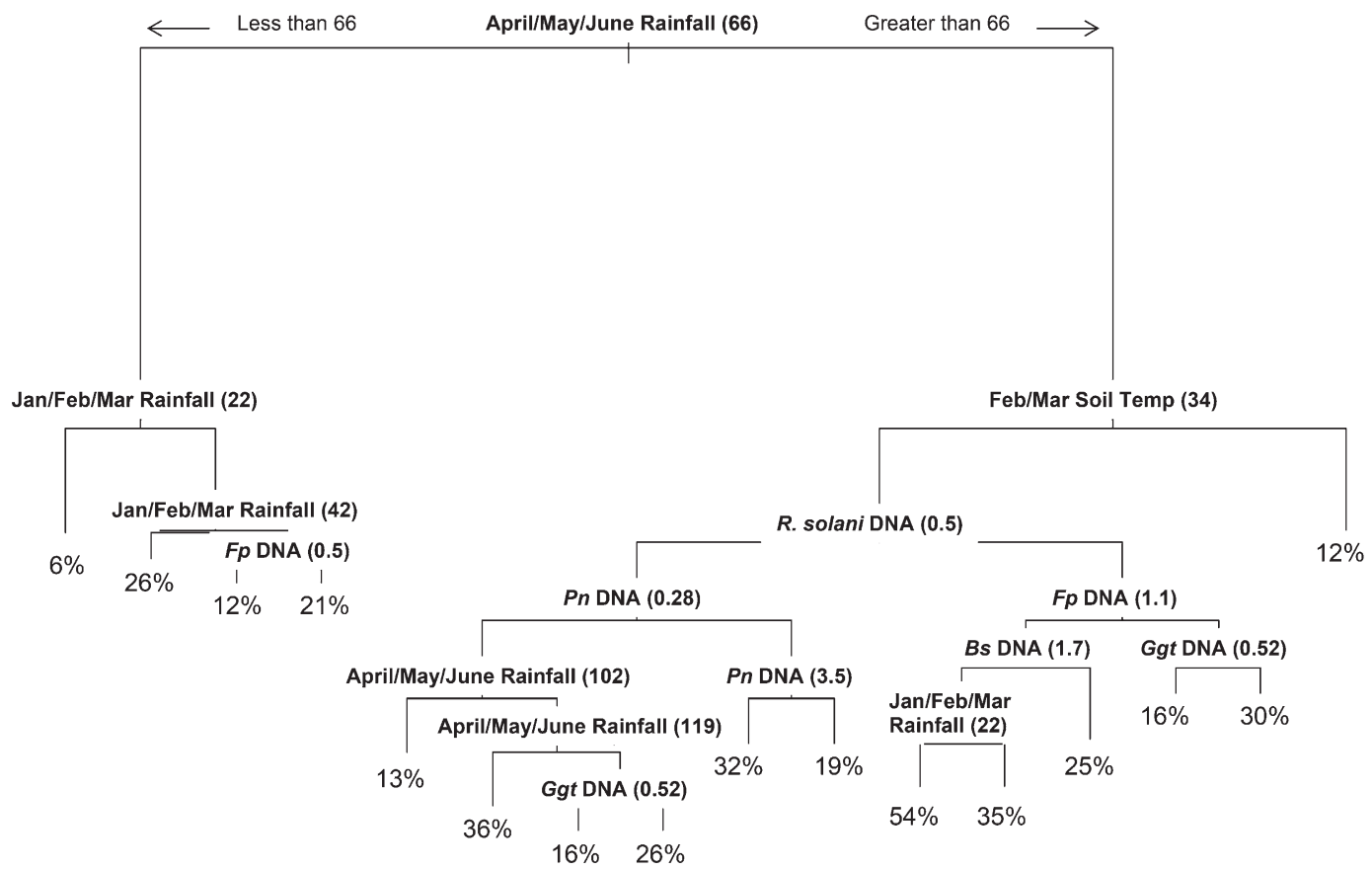

Fig. 5. Regression tree of predicted disease severity given Rhizoctonia solani AG-8, Fusarium pseudograminearum (Fp) Pratylenchus neglectus (Pn), and G. graminis var. tritici (Ggt) pathogen DNA levels and different levels of autumn (April-May-June) rainfall, summer (February-March) soil temperature (temp), and summer (January-February-March) rainfall. Critical levels of variables are within parenthesis with units for rainfall (millimeters), pathogen DNA (log DNA + $1 \mathrm{pg} / \mathrm{g}$ of soil), and soil temperature in degrees Celsius. Follow the diagram to the right for levels exceeding critical levels and to the left for levels less than critical levels. Disease severity predicted by the model is represented by the proportional numbers at the bottom. 
greater in many instances when other pathogen DNA concentrations (i.e., P. neglectus, F. pseudograminearum, and B. sorokiniana) were lower.

Many pathologists have reported the association of less $R$. solani inoculum and disease pressure under conditions following higher summer rainfall in Australia and the United States $(15-17,19,28,29,34,42)$. Mazzola and $\mathrm{Gu}$ (28) reported that $R$. solani AG-8 interacted with the microbial community in a diverse way and, with time, would be outcompeted from increased microbial activity under higher moisture conditions. Roget et al. $(41,42)$ also reported a "suppressiveness" of $R$. solani in soils where microbial activity was accelerated from increased moisture and organic matter following summer rainfall events. Gill et al. (19) reported that disease severity caused by $R$. solani AG-8 decreased by $69 \%$ under wetter soil moisture levels of -3 to $-10 \mathrm{kPa}$ and concluded that soil microbial activity increased under increasing soil moisture, postulating that the activity was responsible for suppressive effects on the Rhizoctonia fungus.

Okubara et al. (34) also reported lower $R$. solani AG-8 pathogen DNA levels under environments with higher precipitation in a survey conducted in the PNW of the United States. There were also lower concentrations of $R$. solani AG-8 pathogen DNA following broadleaf crops. $R$. solani AG-8 pathogen DNA was most strongly negatively correlated with summer rainfall in the PNW of the United States (July to September, $r=-0.35, P<0.0001$ ). Our results also showed that Rhizoctonia disease incidence and overall disease severity were significantly reduced under conditions of higher (January-February-March) summer rainfall, when modeled with $R$. solani AG-8 pathogen DNA. Thus, our results agree with those of several others reporting lower Rhizoctonia disease and inoculum following higher moisture patterns $(5,16,19,28,34,41,42)$. Our study also showed significant differences in disease incidence across years as well as within seasons.

In our study, interactions between $R$. solani AG-8 and environment differed between 2010 and 2012 according to the logistic regression model. Although Rhizoctonia root rot incidence was only weakly associated with presow DNA levels in preliminary correlations, there were large differences in environmental conditions between both seasons. In 2010, which was generally characterized as a warm, dry year, the impact of $R$. solani AG-8 was greater in CVT zones with higher autumn rainfall and cool autumn or summer temperatures. In 2012, which was characterized as having cooler than average autumn temperatures, there was a greater risk of Rhizoctonia root rot in CVT zones with relatively warm, dry summers and cool autumn temperatures. The reduced slope of the logistic curve for 2012 compared with 2010 indicates that $R$. solani AG-8 had greater impact on root health in 2010. This indicates that, in the case of this study, $R$. solani AG-8 was driving the root disease complex interaction between pathogen levels presowing and environment and cereal root health across different regions and seasons.

Aside from showing the magnitude of root disease incidence variation across 3 years, this study also shows the diverse interactions between seasonal environmental conditions as well as the pathogenic microbial community measured by PreDicta-B and the environments of crop production similar to those reported by others $(4,5,8,9,18,34,55)$. Rhizoctonia and root-lesion nematode disease incidence measured by visually rating plants were most closely correlated with overall disease severity and root health. However, relationships between $R$. solani AG-8 pathogen DNA, Rhizoctonia disease incidence, and April-May-June and JanuaryFebruary-March rainfall parameters were most closely associated with overall disease severity and declining root health. The regression tree analysis showed that pathogen DNA levels were interactive in somewhat of a complex where, under certain conditions, disease severity was greater when certain pathogen levels (such as $F$. pseudograminearum and B. sorokiniana) were lower under certain environmental conditions. P. neglectus and the take-all pathogen DNA (G. graminis var. tritici) had more significant effects on disease severity at lower $R$. solani AG-8 pathogen DNA levels, while $F$. pseudograminearum dominated to the left of the disease severity regression tree under lower AprilMay-June rainfall conditions and higher January-February-March summer rainfall conditions where $R$. solani AG-8 pathogen DNA was not interactive. Thus, this study suggests that certain combinations of both pathogen levels and environments lead to greater disease severity and decline in root health. There is room in future reports of this study to include crop rotational strategies as an additional parameter to include in the disease severity model.

Several studies have reported significant effects of cropping rotational systems and tillage practices on the incidence of Rhizoctonia root rot and other root diseases $(16,18,20,22,23,34,38$, 40-42,44,45,47,48,54,55). Trends have shown decreased Rhizoctonia spp. incidence under conditions following a broadleaf crop and barley crops $(34,42,47)$. Smiley et al. (55) reported increased Rhizoctonia root rot following continuous winter wheat compared with following no-till winter pea. However, they reported that inoculum density (picograms of DNA per gram of soil) of $R$. solani AG-8 did not change across crop rotations and cropping systems. Schroeder and Paulitz (47) reported higher Rhizoctonia root rot and $R$. solani AG-8 hyphal activity after 3 to 4 years of transitioning to direct seeding. Although these trends are interesting to report, crop rotational history was not taken into account in this portion of this modeling study because plants were sampled from cereal crops from year to year and likely resembled pressure found in continuous cropping systems lacking rotation.

Environmental conditions and expression of cereal root disease varied significantly both in regional locations outlined by the CVT zones and between the 3 years in this study. The analysis from this study shows that the effects of temperature and rainfall were significant across regions and all 3 years and the incidence and severity cereal root disease varied between the CVT zones (57). Also, pathogen levels varied between the regional zones; zone 6, for example, had greater amounts of $R$. solani AG-8, G. graminis var. tritici, and $F$. pseudograminearum and resulted in the greatest disease severity during the course of this study.

Rhizoctonia root rot $(R$. solani AG- 8$)$ had the greatest impact on root health across years. Fusarium spp., Pratylenchus spp., and $B$. sorokiniana were often detected in the fields. However, their contribution to explaining variation in root health was relatively low. Of the Pratylenchus spp. assessed, P. neglectus was the most widespread and in greatest abundance, occurring in over $39 \%$ of the fields (53). P. teres was detected in $9 \%$ of fields. Presow and postharvest pathogen DNA levels were the most correlated for $P$. thornei, P. neglectus, and B. sorokiniana, followed by $R$. solani AG-8.

Root diseases in the Northern region of Australia encompassing parts of Queensland and New South Wales are dominated by a different pathogen complex (namely, $P$. thornei, $P$. neglectus, and Fusarium spp. causing crown rot) and are not as affected by environment, where pathogen DNA levels are better predictors of in-crop disease $(49,59)$. Even though the combination of environmental and pathogen DNA parameters in this survey were significant and useful in interpreting disease interactions and relationships, pathogen and environmental parameters explained a relatively low proportion of variation in root health ranging from 2 to $11 \%$, with environmental parameters explaining most of the relationships. Similar to the findings of Okubara et al. (34), these results show that, regardless of the small amount of variation explained by the statistical analyses, substantial biological inferences can be drawn that agree with that of others $(17,28,41,42)$.

This study shows that data from different fields across a broad range of districts and seasons can be used to model variation in root health, similarly to data of the take-all model (8). These results provided the framework for an interpretive logistic algorithmic model that more accurately estimates the risk of cereal root diseases 
based on presow pathogen DNA levels and actual field survey root disease measurements taken across years. When samples come into the lab and DNA levels are reported, the model could potentially be used to provide an associated risk of disease severity based on the sample location, survey results, and potential growing season scenarios. This predictive model will be expanded and confirmed with data from future seasons across years and provided with the pathogen DNA test results to provide more accurate root disease predictions. With further development, this root health model will allow growers and industry to more accurately predict yield loss based on PreDicta-B soil DNA analyses and more accurately adjust their cropping programs to minimize risk of yield loss due to soilborne cereal root diseases.

\section{ACKNOWLEDGMENTS}

We thank all of the co-operators involved in the focus field surveys, including growers and farming systems groups throughout Western Australia, and DAFWA staff for taking, storing, and processing root samples. Funding was received from the Australian Grains Research and Development Corporation through the projects "Molecular Diagnostics Centre for delivery of training and diagnostics for soilborne disease management" (DAS00115), "Putting the Focus on Profitable Crop and Pasture Sequencing" (DAW00213), and "Identification and characterization of disease suppressive soils in the Western Region" (DAW00201).

\section{LITERATURE CITED}

1. Agrios, G. N. 2005: Pages 77-79 in: Plant Pathology, 5th ed. Elsevier Academic Press, Burlington, MA.

2. Anderson, W. K., and Garlinge, J. R. 2000. The Wheat Book: Principles and Practice. Pages 217-219 in: Agric. West. Aust. Bull. 4443.

3. Backhouse, D., Abubakar, A. A., Burgess, L. W., Dennis, J. I., Hollaway, G. J., Wildermuth, G. B., Wallwork, H., and Henry, F. J. 2004. Survey of Fusarium species associated with crown rot of wheat and barley in eastern Australia. Australas. Plant Pathol. 33:255-261.

4. Backhouse, D., and Burgess, L. W. 2002. Climatic analysis of the distribution of Fusarium graminearum, F. pseudograminearum and F. culmorum on cereals in Australia. Australas. Plant Pathol. 31:321-328.

5. Barnett, S. J., Roget, D. K., and Ryder, M. H. 2006. Suppression of Rhizoctonia solani (AG-8) induced disease on wheat by the interaction between Pantoea, Exiguobacterium, and Microbacteria. Aust. J. Soil Res. 44:331-342.

6. Bentley, A. R., Cromey, M. G., Farrokhi-Nejad, R., Leslie, J. F., Summerell, B. A., and Burgess, L. W. 2006. Fusarium crown and root rot pathogens associated with wheat and grass stem bases on the South Island of New Zealand. Australas. Plant Pathol. 35:495-502.

7. Bentley, A. R., Tunali, B., Nicol, J. M., Burgess, L. W., and Summerell, B. A. 2006. survey of Fusarium species associated with wheat and grass stem bases in northern Turkey. Sydowia 58:163-177.

8. Bithell, S. L., McKay, A., Butler, R. C., Herdina, Ophel-Keller, K., Hartley, D., and Cromey, M. G. 2012. Predicting take-all severity in second-year wheat using soil DNA concentrations of Gaeumannomyces graminis var. tritici determined with qPCR. Plant Dis. 96:443-451

9. Bithell, S. L., McLachlan, A. R. G., Hide, C. C. L., McKay, A., and Cromey, M. G. 2009. Changes in post-harvest levels of Gaeumannomyces graminis var. tritici inoculums in wheat fields. Australas. Plant Pathol. 38: 277-283.

10. Bockus, W. W., Bowden, R. L., Hunger, R. M., Morrill, W. L., Murray, T. D., and Smiley, R. W. 2010. Compendium of Wheat Diseases, 3rd ed. The American Phytopathological Society, St. Paul, MN.

11. Burgess, L. W., Wearing, A. H., and Toussoun, T. A. 1975. Surveys of Fusaria associated with crown rot of wheat in eastern Australia. Aust. J. Agric. Res. 26:791-799.

12. Chakraborty, S., Liu, C. J., Mitter, V., Scott, J. B., Akinsanmi, O. A., Ali, S., Dill-Macky, R., Nicol, J., Backhouse, D., and Simpfendorfer, S. 2006. Pathogen population structure and epidemiology are keys to wheat crown rot and Fusarium head blight management. Australas. Plant Pathol. 35: 643-655.

13. Colbach, N., Meynard, J. M., Duby, C., and Huet, P. 1999. A dynamic model of the influence of rotation and crop management on the disease development of eyespot. Proposal of cropping systems with low disease risk. Crop Prot. 18:451-461.

14. Cook, R. J. 1968. Fusarium root and foot rot of cereals in the Pacific Northwest. Phytopathology 58:127-131.
15. Cook, R. J. 1992. Wheat root health management and environmental concern. Can. J. Plant Pathol. 14:76-85.

16. Cook, R. J., Schillinger, W. F., and Christiansen, N. W. 2002. Rhizoctonia root rot and take-all of wheat in diverse direct seed spring cropping systems. Can. J. Plant Pathol. 24:349-358.

17. Cook, R. J., and Veseth, R. J. 1991. Wheat Health Management. American Phytopathological Society, St. Paul, MN.

18. Evans, M. L., Halloway, G. J., Dennis, J. I., Correll, R., and Wallwork, H. 2010. Crop sequence as a tool for managing populations of Fusarium pseudograminearum and F. culmorum in South-eastern Australia. Australas. Plant Pathol. 39:376-382.

19. Gill, J., Sivasithamparam, K., and Smettem, K. J. 2001. Effect of soil moisture at different temperatures on Rhizoctonia root rot of wheat seedlings. Plant Soil 231:91-96.

20. Halloway, G. J., Taylor, S. P., Eastwood, R. F., and Hunt, C. H. 2000. Effect of field crops on density of Pratylenchus in Southeastern Australia; Part 2: P. thornei. J. Nematol. 32:600-608.

21. Herdina, and Roget, D. K. 2000. Prediction of take-all disease risk in field soils using a rapid and quantitative DNA soil assay. Plant Soil 227:87-98.

22. Jarvis, R., and Brennan, R. F. 1986. Timing and intensity of surface cultivation and depth of cultivation affect Rhizoctonia patch and wheat yield. Aust. J. Exp. Agric. 26:703-708.

23. Khangura, R. K., MacNish, G. C., MacLeod, W. J., Vanstone, V. A, Hanbury, C. D., Loughman, R., and Speijers, J. E. 2013. Current status of cereal root diseases in Western Australia under intensive cereal production and their comparison with the historical survey conducted during 19761982. J. Phytopathol. 61:11-12.

24. Lawes, R., and Renton, M. 2010. The Land Use Sequence Optimiser (LUSO): A theoretical framework for analyzing crop sequences in response to nitrogen, disease and weed populations. Crop Pasture Sci. 61: 835-843.

25. Llewellyn, R. S., D’Emden, F. H., and Kuehne, G. 2012. Extensive use of no-tillage in grain growing regions of Australia. Field Crops Res. 132: 204-212.

26. MacNish, G. C. 1983. Rhizoctonia patch in Western Australia grain belt. Australas. Plant Pathol. 12:49-50.

27. Matthew, J., Herdina, and Whisson, D. 1995. DNA probe specific to Rhizoctonia solani anastomosis group 8. Mycol. Res. 99:745-750.

28. Mazzola, M., and Gu, Y.-H. 2002. Wheat genotype-specific induction of soil microbial communities suppressive to disease incited by Rhizoctonia solani Anastomosis Group (AG) 5 and (AG) 8. Phytopathology 92: 1300-1307.

29. McKay, A., Roget, D., Hannam, R., and Ophel-Keller, K. 2008: Pages 33-44 in: Root Disease Risk Management: Resource Manual. PIRSA Publishing, Adelaide, SA, Australia.

30. Murray, G. M., and Brennan, J. P. 2009. Estimating disease losses to the Australian wheat industry. Australas. Plant Pathol. 38:558-570.

31. Murray, G. M., and Brennan, J. P. 2010. Estimating disease losses to the Australian barley industry. Australas. Plant Pathol. 39:85-96.

32. Nicol, J. M., Bolat, N., Bagci, A., Trethowan, R. T., William, M., Hekimhan, H., Yildirim, A. F., Sahin, E., Eleckcioglu, H., Toktay, H., Tunali, B., Hede, A., Taner, S., Braun, H. J., Van Ginkel, M., Arisoy, Z., Yorgancilar, A., Tulek, A., Erdurmus, D., Buyuk, O., and Aydogdu, M. 2007. The international breeding strategy for the incorporation of resistance in bread wheat against the soilborne pathogens (dryland root rot and cyst and lesion cereal nematodes) using conventional and molecular tools. Pages 125-137 in: Wheat Production in Stressed Environments. Developments in Plant Breeding, Vol. 12. H. T. Buck, ed., CIMMYT, Ankara, Turkey.

33. Nicol, J. M., Davies, K. A., Hancock, T. W., and Fisher, J. M. 1999. Yield loss caused by Pratylenchus thornei on wheat in South Australia. J. Nematol. 31:367-376.

34. Okubara, P. A., Schroeder, K. L., Abatzoglou, J. T., and Paulitz, T. C. 2014. Agroecological factors correlated to soil DNA concentrations of Rhizoctonia in dryland wheat production zones of Washington state, USA. Phytopathology 104:683-691.

35. Ophel Keller, K., Engel, B., and Heinrich, K. 1995. Specific detection of Gaeumannomyces graminis var. tritici in soil using polymerase chain reaction. Mycol. Res. 99:1385-1390.

36. Ophel-Keller, K., McKay, A., Hartley, D., Herdina, and Curran, J. 2008. Development of a routine DNA-based testing service for soilborne diseases in Australia. Australas. Plant Pathol. 37:243-253.

37. Orion, D., Krikun, J., and Sullami, M. 1979. The distribution, pathogenicity and ecology of $P$. thornei in the Northern Negev. Phytoparasitica 7: 3-9.

38. Paulitz, T. C., Smiley, R. W., and Cook, R. J. 2002. Insights into the prevalence and management of soilborne cereal pathogens under direct seeding in the Pacific Northwest, U.S.A. Can. J. Plant Pathol. 24: 416-427. 
39. Poole, G. J., Smiley, R. W., Walker, C., Huggins, D., Rupp, R., Abatzoglou, J., Garland-Campbell, K., and Paulitz, T. C. 2013. Effect of climate on the distribution of Fusarium species causing crown rot of wheat in the Pacific Northwest of the United States. Phytopathology 103:1130-1140.

40. Roget, D. K., and Rovira, A. D. 1991. The relationship between incidence of infection by the take-all fungus (Gaeumannomyces graminis var. tritici), rainfall and yield of wheat in South Australia. Aust. J. Exp. Agric. 31:509-513.

41. Roget, D. K. 1995. Decline in root rot (Rhizoctonia solani AG-8) in wheat in a tillage and rotation experiment at Avon, South Australia. Aust. J. Exp. Agric. 35:1009-1013.

42. Roget, D. K., Neate, S. M., and Rovira, A. D. 1996. Effect of sowing point design and tillage practice on the incidence of Rhizoctonia root rot, takeall, and cereal cyst nematode in wheat and barley. Aust. J. Exp. Agric. 36: 683-693.

43. Robertson, M. J., Lawes, R. A., Bathgate, A., Byrne, F., White, P., and Sands, R. 2010. Determination of the proportion of break crops on Western Australia broadacre farms. Crop Pasture Sci. 61:203-213.

44. Rovira, A. D. 1986. Influence of crop rotation and tillage on Rhizoctonia bare patch of wheat. Phytopathology 76:669-673.

45. Schillinger, W. F., and Paulitz, T. C. 2006. Reduction of Rhizoctonia bare patch in wheat with barley rotations. Plant Dis. 90:302-306.

46. Schoeny, A., Jeuffroy, M.-H., and Lucas, P. 2001. Influence of take-all epidemics on winter wheat yield formation and yield loss. Phytopathology 91:694-701.

47. Schroeder, K. L., and Paulitz, T. C. 2006. Root diseases of wheat and barley during the transition from conventional tillage to direct seeding. Plant Dis. 90:1247-1253.

48. Seymour, M., Kirkegaard, J. A., Peoples, M. B., White, P. F., and French, R. J. 2012. Break-crop benefits to wheat in Western Australia-Insights from over three decades of research. Crop Pasture Sci. 63:1-16.

49. Sheedy, J. G., McKay, A. C., Lewis, J., Vanstone, V. A., Fletchers, S., Kelly, A., and Thompson, J. P. 2015. Cereal cultivars can be ranked consistently for resistance to root-lesion nematodes (Pratylenchus thornei and P. neglectus) using diverse procedures. Australas. Plant Pathol. 44:175-182.

50. Smiley, R. W., Collins, H. P., and Rasmussen, P. E. 1996. Diseases of wheat in long-term agronomic experiments at Pendleton, Oregon. Plant Dis. 80:813-820.
51. Smiley, R. W., Gourlie, J. A., Easley, S. A., Patterson, L.-M., and Whittaker, R. G. 2005. Crop damage estimates for crown rot of wheat and barley in the Pacific Northwest. Plant Dis. 89:595-604.

52. Smiley, R. W., Gourlie, J. A., Easley, S. A., Patterson, L.-M., and Whittaker, R. G. 2005. Pathogenicity of fungi associated with the wheat crown complex in Oregon and Washington. Plant Dis. 89:949-957.

53. Smiley, R. W., and Machado, S. 2009. Pratylenchus neglectus reduces yield of winter wheat in dryland cropping systems. Plant Dis. 93:263-271.

54. Smiley, R. W., Machado, S., Gourlie, J. A., Pritchett, L. C., Yan, G. P., and Jacobsen, E. E. 2013. Effects of crop rotations and tillage on Pratylenchus spp. In the semi-arid Pacific Northwest United States. Plant Dis. 97: 537-546.

55. Smiley, R. W., Machado, S., Gourlie, J. A., Pritchett, L. C., Yan, G. P., and Jacobsen, E. E. 2013. Influence of semi-arid cropping systems on root diseases and inoculum density of soilborne pathogens. Plant Dis. 97: 547-555.

56. Smiley, R. W., and Patterson, L. M. 1996. Pathogenic fungi associated with Fusarium foot rot of winter wheat in the semiarid Pacific Northwest. Plant Dis. 80:944-949.

57. Stephens, D. J., and Lyons, T. J. 1998. Rainfall-yield relationships across the Australian wheatbelt. Aust. J. Agric. Res. 49:211-223.

58. Taylor, S. P., Holloway, G. J., and Hunt, C. H. 2000. Effect of field crops on population densities of Pratylenchus neglectus and $P$. thornei in Southeastern Australia; Part 1: P. neglectus. J. Nematol. 32:591-599.

59. Thompson, J. P., Owen, K. J., Stirling, G. R., and Bell, M. J. 2008. Rootlesion nematodes (Pratylenchus thornei and P. neglectus): A review of recent progress in managing a significant pest of grain crops in northern Australia. Australas. Plant Pathol. 37:235-242.

60. Vanstone, V. A., Rathjen, A. J., Ware, A. H., and Wheeler, R. D. 1998. Relationship between root lesion nematodes (Pratylenchus thornei and P. neglectus) and performance of wheat varieties. Aust. J. Exp. Agric. 38: 181-188.

61. Venables, W. N., and Smith, D. M. 2012. In: An Introduction to R: Notes on R: A Programming Environment for Data Analysis and Graphics, version 2.15.3. R-Core Team. University of Adelaide, Adelaide, SA.

62. Yeates, J. S., Fang, C. S., and Parker, C. A. 1986. Distribution and importance of oat attacking isolates of Gaeumannomyces graminis var. tritici in Western Australia. Trans. Br. Mycol. Soc. 86:145-152. 